\title{
Seismic reflection analysis of the Manson Impact Structure, Iowa
}

\author{
D. Keiswetter \\ Goophex Limited, Raleigh, North Carolina \\ R. Black and D. Steeples \\ Department of Geology, University of Kansas, Lawrence
}

Abstract. Our combined interpretation of new, high-resolution seismic reflection data and reprocessed, but previously published, industrial Vibroseis data indicates that the Manson Impact Structure, Iowa, has an apparent crater diameter of $35 \mathrm{~km}$, an annular trough diameter of around $21 \mathrm{~km}$, a shallow floor $(0.6-0.7 \mathrm{~km})$, and a central uplift that has a minimum diameter of $7.5 \mathrm{~km}$. The two reflection lines are coincidentally located along an east-west radial transect and are constrained by shallow drill information. Results from the two data sets are correlative; both data sets were instrumental to the final interpretation due to the trade-off between resolution and depth of energy penetration. Based on the combined interpretation, structural uplift of the central peak is estimated to be around $2.8 \mathrm{~km}$. Onlapping seismic sequences are present at the eastern edge of the central uplift. These seismic packages, observed only in the high-resolution line, are interpreted to represent impact breccia or debris material that was shed from the central peak or dynamically transported from outside of the crater.

\section{Introduction}

Although unequivocal identification of planar deformation features found at the Manson Impact Structure (MIS), Iowa, has been documented by other researchers [Short, 1966; Hartung and Anderson, 1989; Hartung et al., 1990; Anderson and Hartung, 1992; Anderson et al., 1993; Short and Gold, 1993], structural and stratigraphic details of the MIS are difficult to discern due to the presence of 30- to 100-m-thick Pleistocene till that covers the area. The current structural model, based on Vibroseis data and drill information, closely resembles configurations of general impact models [Anderson and Hartung, 1992]. The primary objective here is to present and interpret colocated seismic reflection lines in order to substantiate and expand the structural model by Anderson and Hartung [1992].

Two seismic reflection data sets were used in this study (Figure 1); a 17-km-long high-resolution line that images features in the depth range of $40 \mathrm{~m}$ to over $1000 \mathrm{~m}(0.05$ to 0.75 $s$ two-way travel time), and a $22-\mathrm{km}$, east-west Vibroseis line that targets reflectors in the depth ranges from around $400 \mathrm{~m}$ to greater than $15,000 \mathrm{~m}$ (around 0.3 to $6 \mathrm{~s}$ two-way travel time). The shallow reflection data tie drill data that were acquired to characterize the Manson Impact event [Anderson et al., 1993] with the deeper-targeted Vibroseis data. Specific goals of the high-resolution reflection research are to resolve, in greater detail, the structure and stratigraphy of the central uplift, annular trough, and terrace terrane, to locate the presence (or absence) of shallow faults and fault zones, and to identify the internal geometry of debris flows within the impact structure. The Vibroseis data target gross structural features, such as the

\footnotetext{
Copyright 1996 by the American Geophysical Union.
}

Paper number 95JB03117

0148-0227/96/95JB-03117\$05.00 presence of a central uplift, deep structural trends, and the lateral extent of the apparent crater. Although the Vibroseis line has been previously interpreted [Sharpton and Grieve, 1990; Anderson and Hartung, 1992], we reprocessed the data to improve the frequency content and coherency of shallow reflectors and to ensure that the two data sets had been processed similarly.

Seismic reflection surveys have been used previously to characterize other craters of impact origin, such as the Dumas [Sawatzky, 1976], Ries [Pohl et al., 1977], Siljan [Juhlin and Pedersen, 1987], Montagnais [Jansa et al., 1989], Chicxulub [Hildebrand and Boynton, 1990], Hartney and Viewfield structures [Sawatzky, 1975, 1990], Avack Structure [Kirschner et al., 1992], and the Chesapeake Bay crater [Poag et al., 1994].

This research was conducted as part of a multiagency research initiative that was organized in 1991 to examine the MIS in detail and determine its relation to the $\mathrm{K} / \mathrm{T}$ boundary. The multiyear, multidiscipline research program was coordinated by the U.S. Geological Survey and the Iowa Department of Natural Resources Geological Survey Bureall. The collaborative results confirm that Manson is an impact structure based on its circular shape, its central uplift, and the presence of shocked quartz and other minerals [Koerbel and Anderson, 1995]. The seismic reflection data presented herein were interpreted with this knowledge.

\section{Research at the Manson Impact Site}

A geologically anomalous area located in northwest Iowa, now known as the MIS, was first identified in the 1910s when the presence of a "granite-like rock" was identified at unusually shallow depths. Drill core analyses in the 1950s [Hoppin and Dryden, 1958; Dryden, 1955] confirmed the presence of the shallow Precambrian crystalline basement and indicated that the MIS was cryptovolcanic in origin. A cryptovolcanic origin was questioned, however, when Short [1966] recognized shock metamorphic features in core samples. 


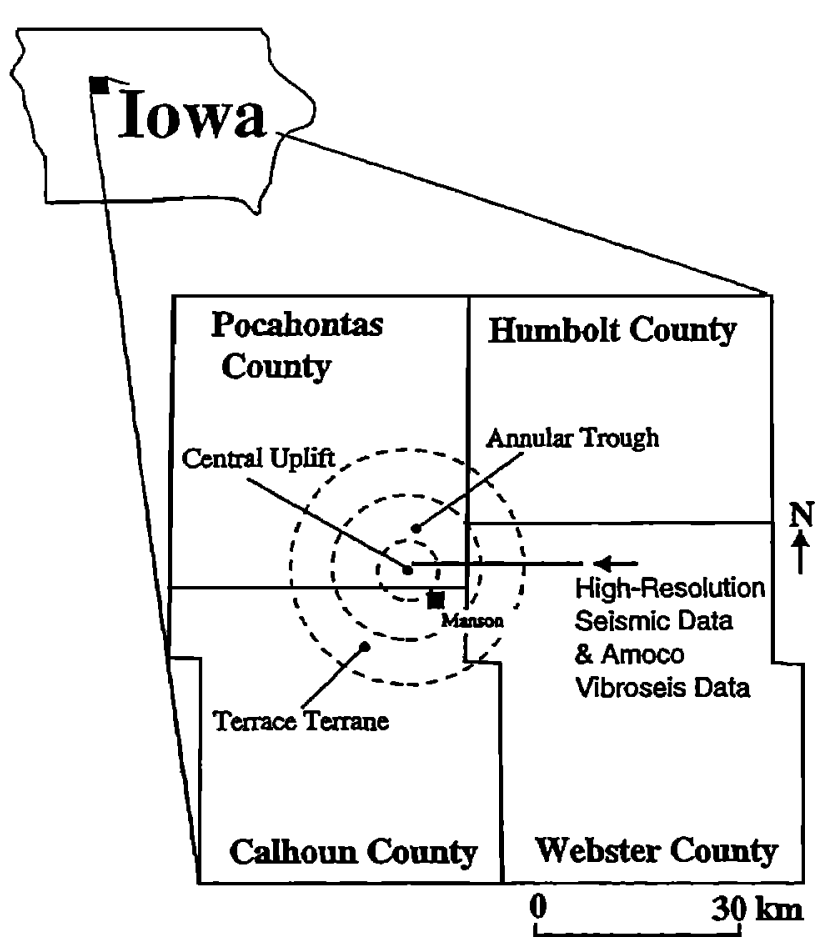

Figure 1. Index map showing the approximate location of the two seismic lines and the major structural components of the Manson Impact Structure (MIS). The two seismic lines are located along the same road.

Research at the MIS accelerated in the late 1980s when the age of the structure was tentatively dated, using radiometric studies of shocked microcline, as contemporaneous with the end of the Cretaceous period [Kunk et al., 1987 1989]. Subsequent radiometric dating by Izett et al. [1993], who used ${ }^{40} \mathrm{Ar} / 39 \mathrm{Ar}$ techniques to date sanidine clasts, indicated that the impact occurred prior to the K-T boundary by about $9 \mathrm{~m}$. This later MIS impact date is $73.8 \pm 0.3 \mathrm{Ma}$, which implies that the bolide struck the Manson area when it was covered by the shallow interior Cretaceous seaway [Izett et al., 1993].

As part of the joint research effort, 12 research holes were drilled into the crater during 1991 and 1992, which produced over $1200 \mathrm{~m}$ of recovered core. Two cores were drilled into the terraced rim, four were drilled in the annular trough, and six were drilled in the central peak. Prior to these new wells, drill data were limited to two cores within the central peak region. Lithologic description of the new cores is discussed by Anderson et al. [1992, 1993], and geochemical analysis is discussed by Koeberl et al. [1993], Blum et al. [1993], and Hartung et al. [1992]. Petrographic studies of core material from the MIS have revealed a variety of impact-induced shock features and include extensive planar deformation features in quartz, K-feldspars, plagioclase, and kinking in biotite [Short and Gold, 1993; Hartung et al., 1990]. Two drill cores, M-3 and M-4, have identified the occurrence of inverted stratigraphy within the terrace terrane [Anderson et al, 1993].

Hartung et al. [1990] presented a general structural model for the MIS based on water well cuttings, gravity and magnetic data, and seismic refraction information. This structural interpretation was later modified and strengthened by Vibroseis reflection data [Anderson and Hartung, 1992]. The proposed structural models of the MIS, however, were questioned by Officer et al. [1992], who disputes an impact origin for the MIS based in part on the "orderly sequence of Cretaceous shales underlain by Paleozoic limestone" that surrounds the MIS.

\section{Local Geology and Seismic Targets}

The MIS is located in west central Iowa where a sequence of Cenozoic, Mesozoic, Paleozoic, and Middle Proterozoic sedimentary rocks overlie a crystalline basement of Proterozoic metamorphic and plutonic rocks [Hartung et al., 1990; Anderson, 1992]. The geologic description of this area is discussed by Hartung et al. [1990], Anderson [1983, 1992] Anderson and Hartung [1992], and Ruhe [1969]. As such, we briefly review their conclusion in order to highlight seismic markers within the MIS area.

The basement complex consists of intrusive granite, garnetiferous gneiss, and diabase dikes [Hoppin and Dryden, 1958; Anderson, 1992]. Overlying the basement crystalline rocks is an eastward thickening wedge of Proterozoic clastic strata associated with the Midcontinent Rift System [Anderson, 1992]. The lithologic boundary between the Proterozoic clastics and crystalline rocks is an excellent seismic reflector and serves as a geophysical marker throughout much of Iowa and Minnesota [Chandler et al., 1989].

Overlying the Proterozoic clastic strata are Paleozoic-aged units dominated by marine carbonates, shales, siltstones, and sandstones [Hartung et al., 1990]. The Paleozoic sequence, which reaches a regional maximum thickness of $750 \mathrm{~m}$, is highly reflective [Chandler et al., 1989; Anderson and Hartung, 1992].

Mesozoic strata deposited in this region occur only as locally preserved outliers [Hartung et al., 1990]. Post crater deposition of Tertiary marine and fluvial sediments is not well known due to erosion [Anderson and Hartung, 1992]. Glacial till, deposited during the Pleistocene, completely obscures bedrock geology in the Manson area [Ruhe, 1969]. The unconformable contact between the tills and bedrock produces an identifiable reflection in this area [Keiswetter et al., 1994].

\section{Seismic Reflection Data}

Vibroseis data were acquired by Amoco Production Research Company in 1985, and the high-resolution reflection data by the University of Kansas in 1991. Acquisition parameters for the two lines are shown in Table 1. Data quality varies, but identifiable reflection events, diffractions, faults, and other seismic modes are present on most of the unprocessed common shot gathers (Figure 2).

The reflection data were processed into common-depth-point (CDP) format using conventional techniques (see the appendix).

Table 1. Acquisition Parameters

\begin{tabular}{lll}
\hline & High-Resolution & Vibroseis \\
\hline Location & Manson, Iowa & Manson, Iowa \\
Source & 50 -caliber rifle & vibrators \\
Receivers & three 40-Hz geophones & unknown \\
Seismograph & EG\&G [240I-X] & unknown \\
Number of channels & 48 & 96 \\
Record length & $0.75 \mathrm{~s}$ & $6 \mathrm{~s}$ \\
Sample interval & $0.5 \mathrm{~ms}$ & $2 \mathrm{~ms}$ \\
Source spacing & $10 \mathrm{~m}$ & $33.5 \mathrm{~m}$ \\
Receiver stations & $5 \mathrm{~m}$ & $33.5 \mathrm{~m}$ \\
In-line offset & $20 \mathrm{~m}$ & $100.5 \mathrm{~m}$ \\
Shooting geometry & end on & split spread \\
\hline
\end{tabular}


Minor differences exist, however, between the processing techniques used for the high-resolution data and for the Vibroseis data, due in part to the different bandwidths of the data. High-resolution reflection data require detailed velocity and spectral analysis and extra care during first-break and surgical muting operations. Dip-moveout corrections were applied before stacking on both lines to enhance the imaging of dipping reflectors and to increase precision during velocity analysis. Both data sets were migrated after stacking to enhance coherency of the reflectors and to collapse diffractions.

\section{Interpretation of Seismic Data}

The MIS can be subdivided into four zones, each characterized by distinct structural characteristics, based on the seismic data. The zones, referred to here as the (1) central uplift, (2) annular trough, (3) terrace terrane, and (4)

A

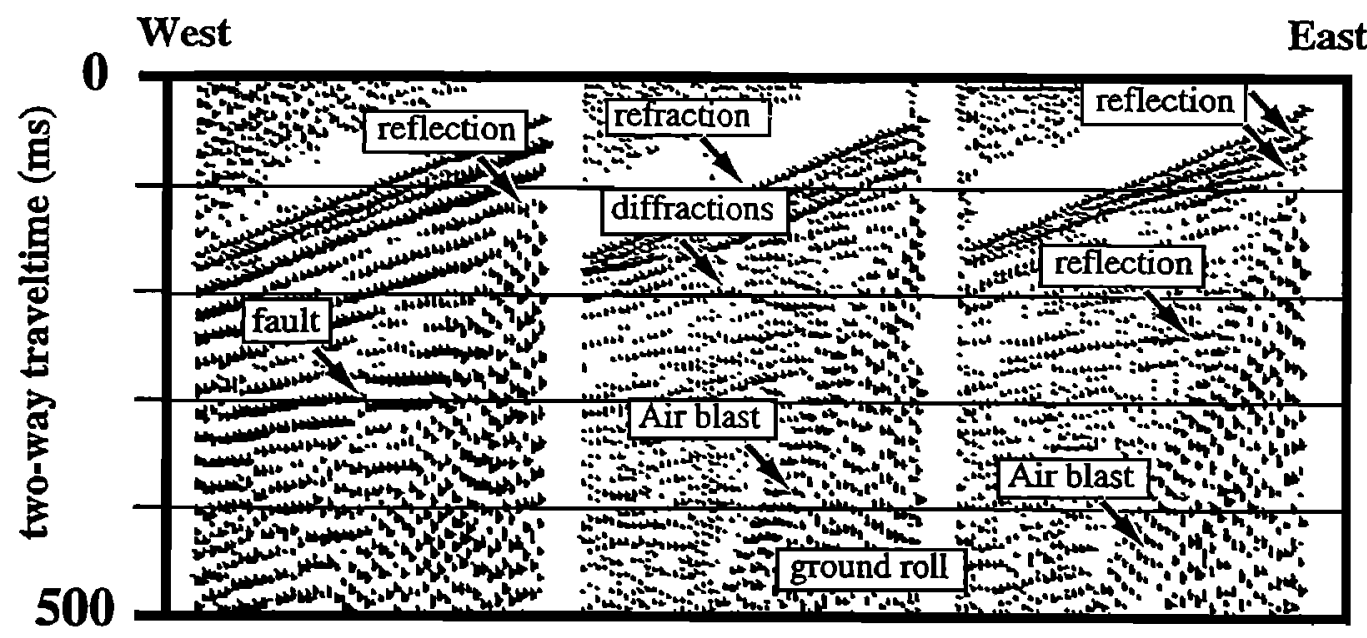

B

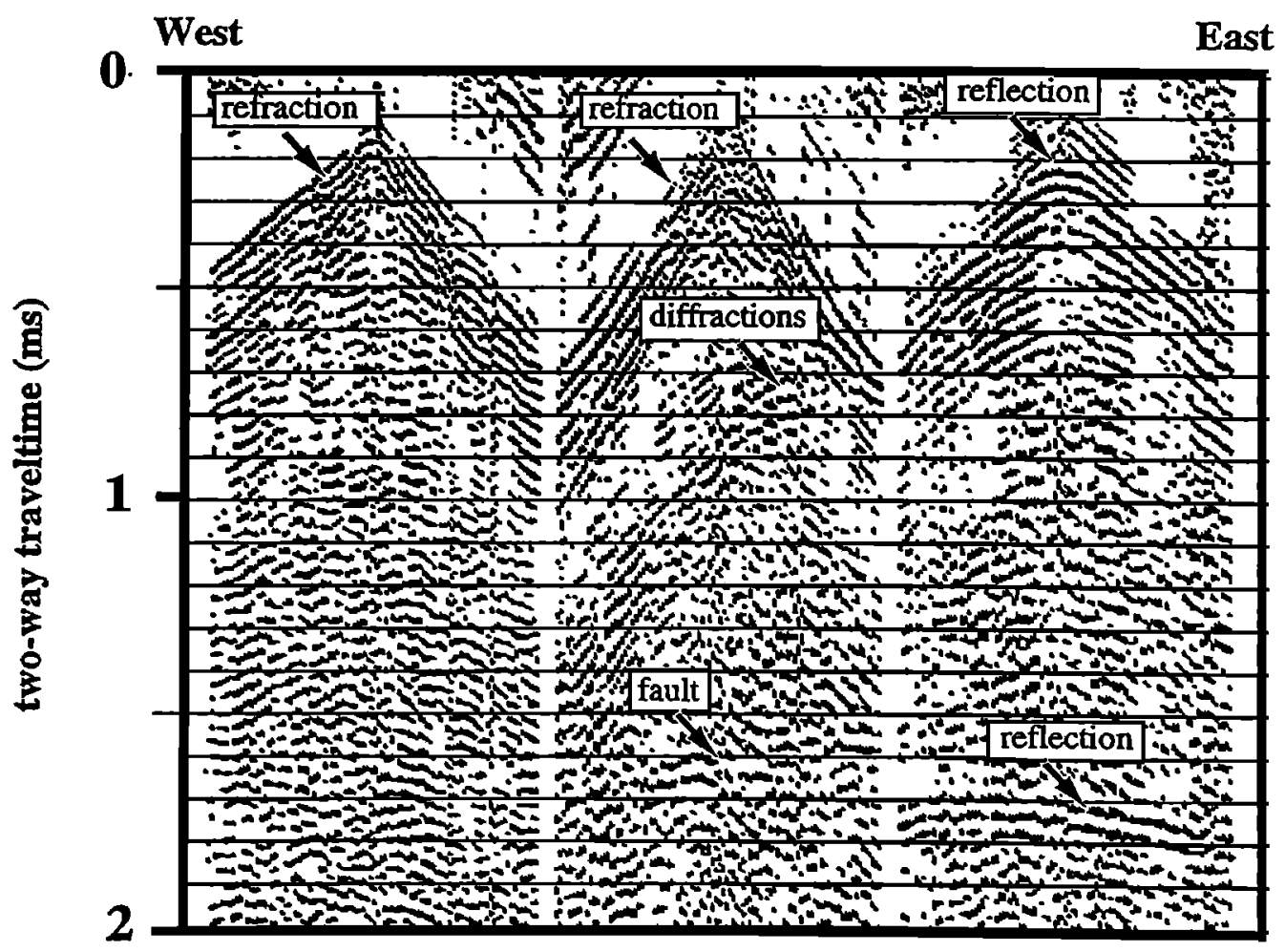

Figure 2. Selected field files (a) of the high-resolution reflection data and (b) the Vibroseis data. Although the data quality varied along each line, identifiable reflection, diffractions, and other seismic modes can be easily identified on the unprocessed field files. See Table 1 for acquisition parameters. These data have been frequency filtered and automatic gain control (AGC) scaled for viewing purposes. 


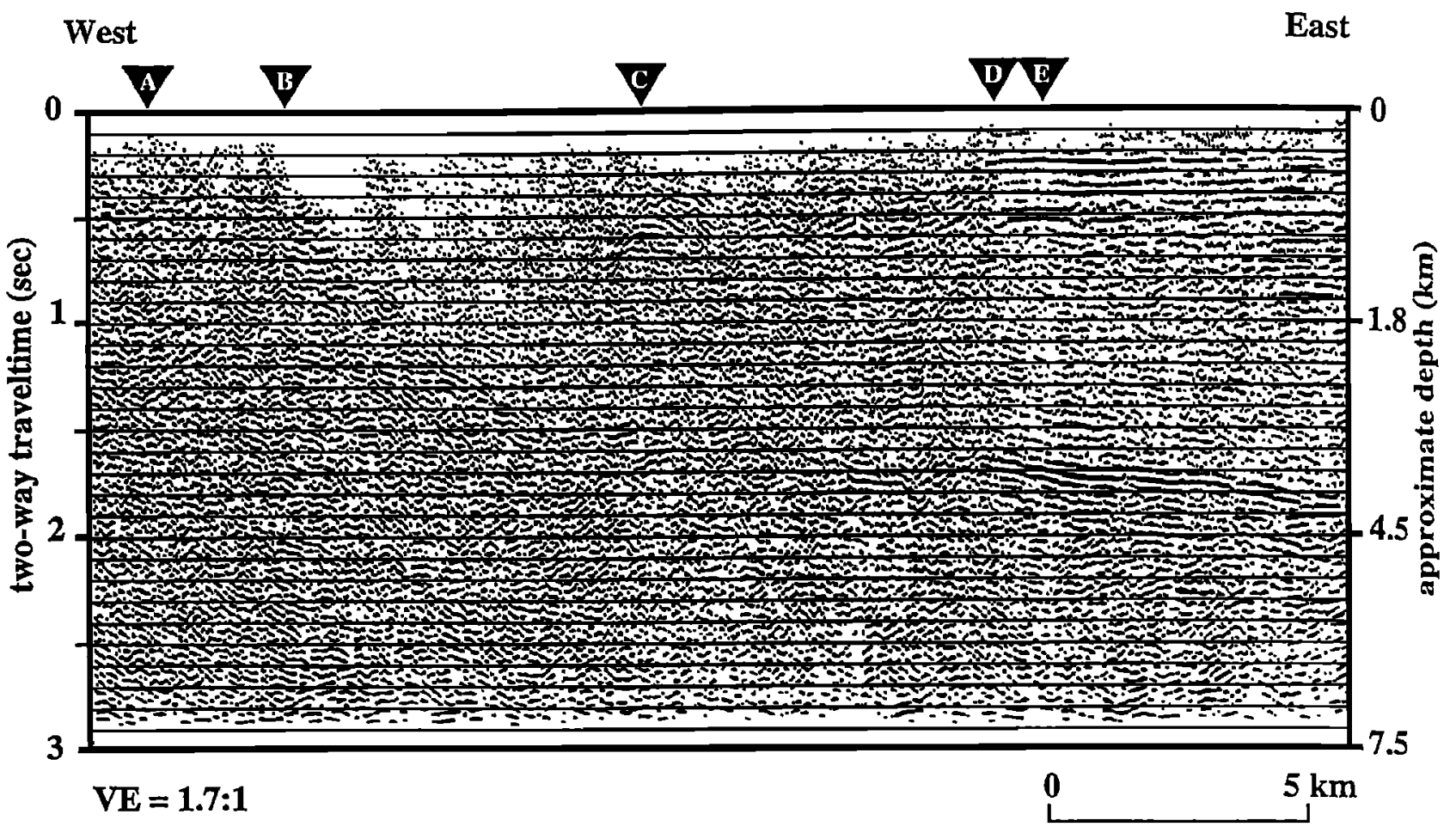

Figure 3a. Common-depth-point stacked section of the uninterpreted Vibroseis data. Interpreted structural elements are indicated by the solid flags.

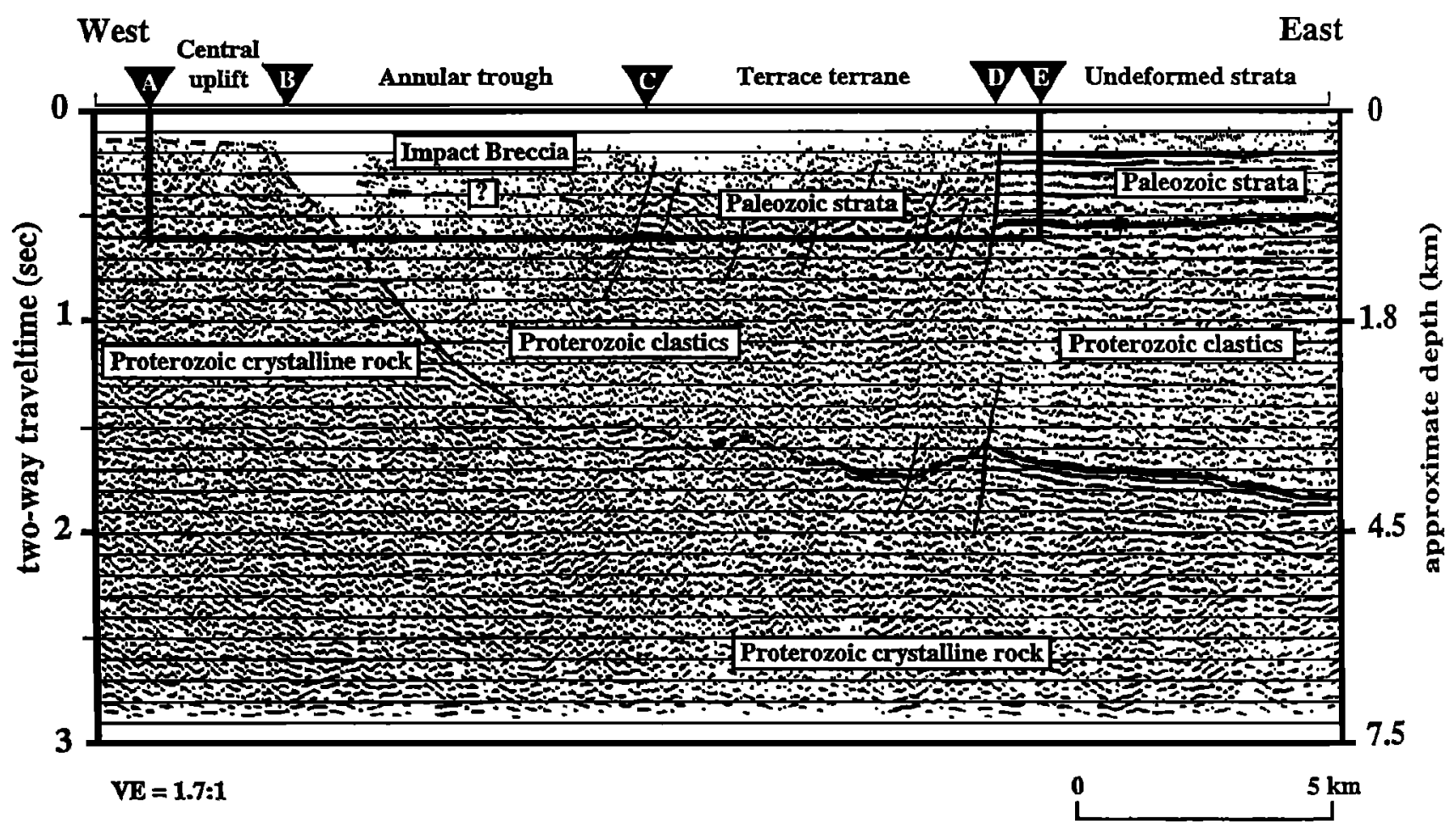

Figure 3b. CDP stacked section of interpreted Vibroseis data. The square stippled rectangle indicates the portion of the crater targeted by the high-resolution seismic-reflection data. See text for discussion. 


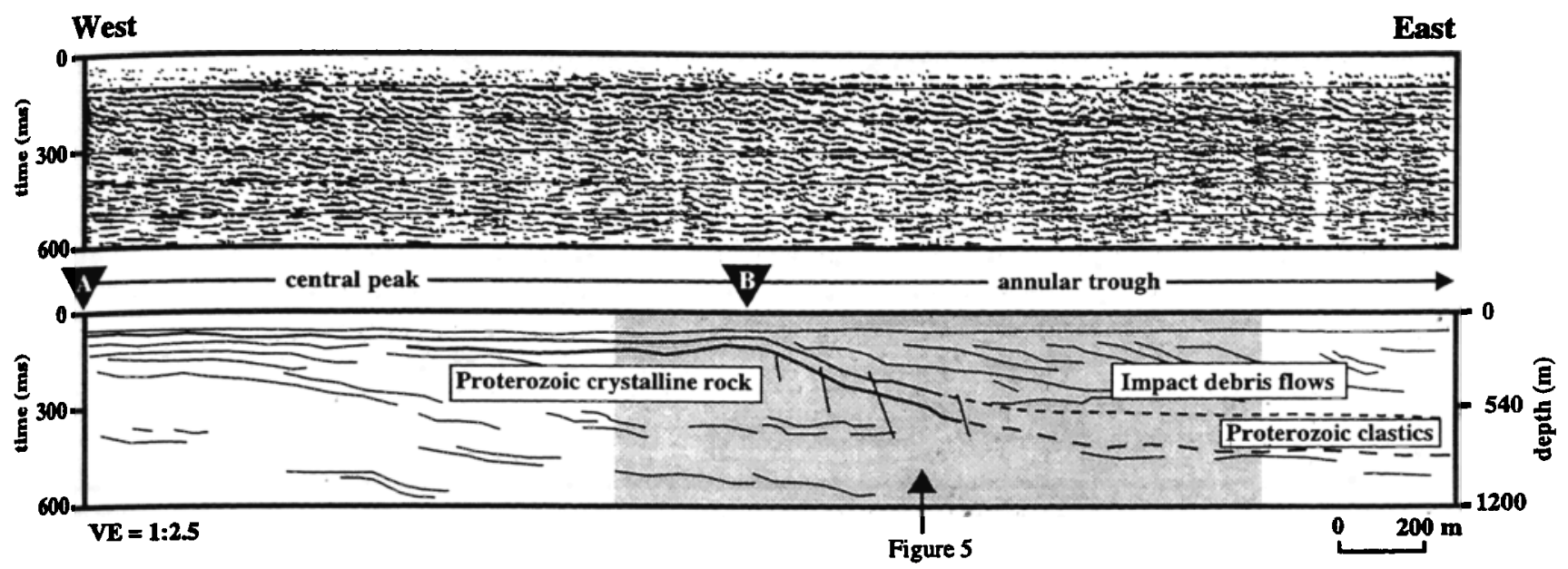

Figure 4a. Common-depth-point (CDP) stacked section of the high-resolution seismic reflection data and associated interpretations. The line is divided for display purposes into six sections, from west to east, such that this section is the western end of the line, and the section in Figure $4 \mathrm{f}$ is the eastern end (compare Figures 1 and 3). The boundaries of the structural elements, also shown in Figure 3, are marked by flags. The stippled portion is enlarged and shown in Figure 5. See text for discussion.

undeformed strata, are similar to those described for general impact models [e.g., Melosh, 1989] and ancillary terrestrial craters [Pohl et al., 1977; Juhlin and Pedersen, 1987; Jansa et al., 1989].

Common-depth-point stacked sections of the two seismic lines are shown in Figures 3 and 4 . To clarify and simplify discussion of the seismic data, the industrial Vibroseis line is herein referred to as "line 1 " (Figure 3), and the high-resolution line as "line 2" (Figure 4).

\section{Central Uplift}

The crystalline central uplift of the MIS is composed primarily of gneiss and has been identified in drill core at depths as shallow as $30 \mathrm{~m}$ [Anderson et al., 1993]. The interface between the crystalline rocks and the overlying impact breccia results in a ringy, high-amplitude reflection on line 2 (Figures $4 \mathrm{a}$ and 5) but it is not imaged by the lower-resolution line 1 (located between markers $A$ and $B$ in Figure 3). The minimum diameter of the central peak is estimated to be over $7 \mathrm{~km}$. This estimate is based on the combination of high-resolution seismic data and drill information, since the seismic data do not extend across the entire central uplift. Additional drilling or geophysical data that establish the western edge of the central peak are required to improve this estimate.

\section{Annular Trough}

The annular trough, located between markers $B$ and $C$ in Figures $3 a, 3 b, 4 a, 4 b$, and $4 c$, refers to the region between the edge of the central uplift and the terrace terrane. Although the annular trough is seismically transparent on the Vibroseis line (Figure 3), stratigraphic details within the impact breccia are observed in the high-resolution reflection data (Figures 4a-4c). At other impact sites imaged by conventional seismic surveys, the annular trough is also reported as being seismically transparent [Pohl et al., 1977; Juhlin and Pedersen, 1987].

We interpret the wavy, somewhat chaotic reflection signatures above $400 \mathrm{~ms}$ two-way travel time in line 2 (Figures $4 a-4 c)$ to represent impact breccia and debris flow units that

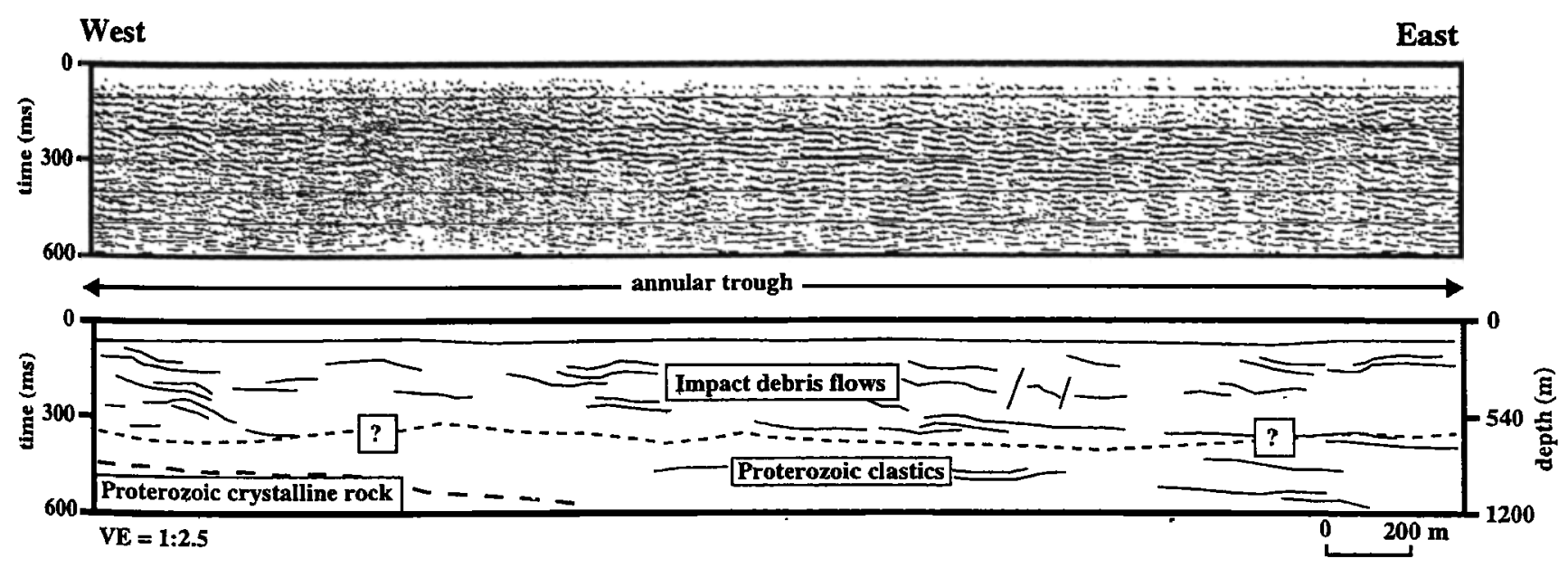

Figure 4b. Continuation of CDP-processed, high-resolution seismic reflection line. See Figure 4a caption for additional details. 


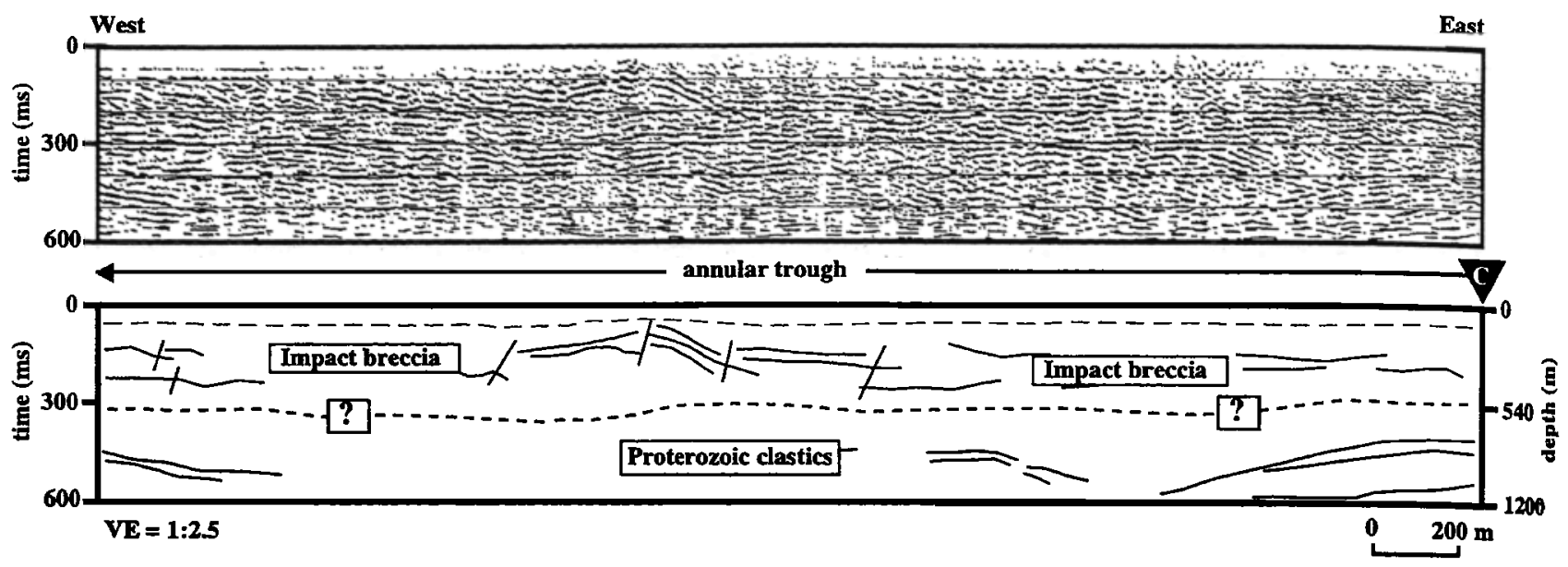

Figure 4c Continuation of CDP-processed, high-resolution seismic reflection line. See Figure 4 a caption for additional details.

were dynamically deposited after impact. A general decrease in the reflectivity at two-way travel times between $350 \mathrm{~ms}$ to 400 ms may represent highly fractured crater floor material (most likely Proterozoic clastic deposits). This unconstrained and unconfirmed interpretation suggests that approximately $600 \mathrm{~m}$ to $700 \mathrm{~m}$ of impact breccia and debris flow material overlie the crater floor.

Prominent sigmoidal features, similar to onlapping sedimentary sequences, are observed near the central peak on the high-resolution line (Figures $4 \mathrm{a}$ and 5). These sigmoidal features may represent material that has been eroded or slumped off the central peak. Conversely, these features could result from debris flows that have transported from outside of the crater. The acoustic impedence contrast producing " the reflections is not known. The transporting mechanism could be have been acoustic fluidization [Melosh, 1983], gravity [Grieve et al., 1981], frictional heating [Dence et al., 1977], or a combination of these. Alternatively, a tsunami-like wave could have transported debris material from outside the crater if, as suggested by Izett et al. [1993], the Manson impact occurred during the time that this area was covered by the Cretaceous seaway. If impact-induced waves did not directly transport the debris flows, the presence of water during crater modification may have still significantly enhanced horizontal transport [Melosh, 1982].

\section{Terrace Terrane}

The terrace terrane is located between markers $C$ and D on lines 1 and 2 (Figures 3 and 4d-4f). Within this zone, individual blocks composed of relatively coherent stratigraphic sequences are bound by normal faults.

A prominent subsurface feature is observed approximately ? $\mathrm{km}$ west of the apparent crater's edge (Figures 3,4d, and 6). This $1.5-\mathrm{km}$-long structure is interpreted to be composed primarily of Paleozoic strata based on a seismic amplitude and frequency comparison with undeformed Paleozoic strata outside of the crater. Indications of normal faulting and laterally varying stratigraphy are present within this feature (Figure 6). Structural deformation extends to depths of more than $1.4 \mathrm{~km}$ (700 ms two-way travel time; Figure 3).

The outer edge of the terrace terrane is identified seismically by an increase in two-way travel time of the Paleozoic reflections and a general decrease in the signal-to-noise level in comparison to the undeformed strata. Within the terrace terrane, reflections

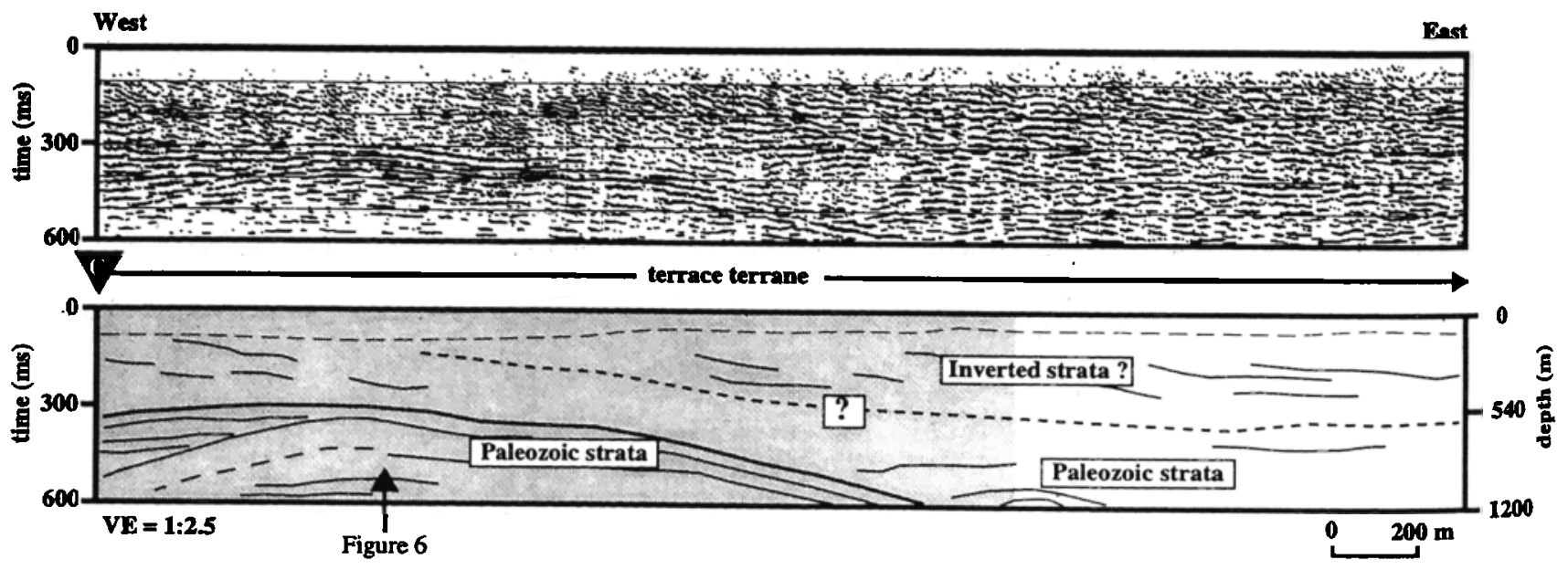

Figure 4d. Continuation of CDP-processed, high-resolution seismic reflection line. The stippled portion is enlarged and shown in Figure 6. See Figure 4a caption for details. 


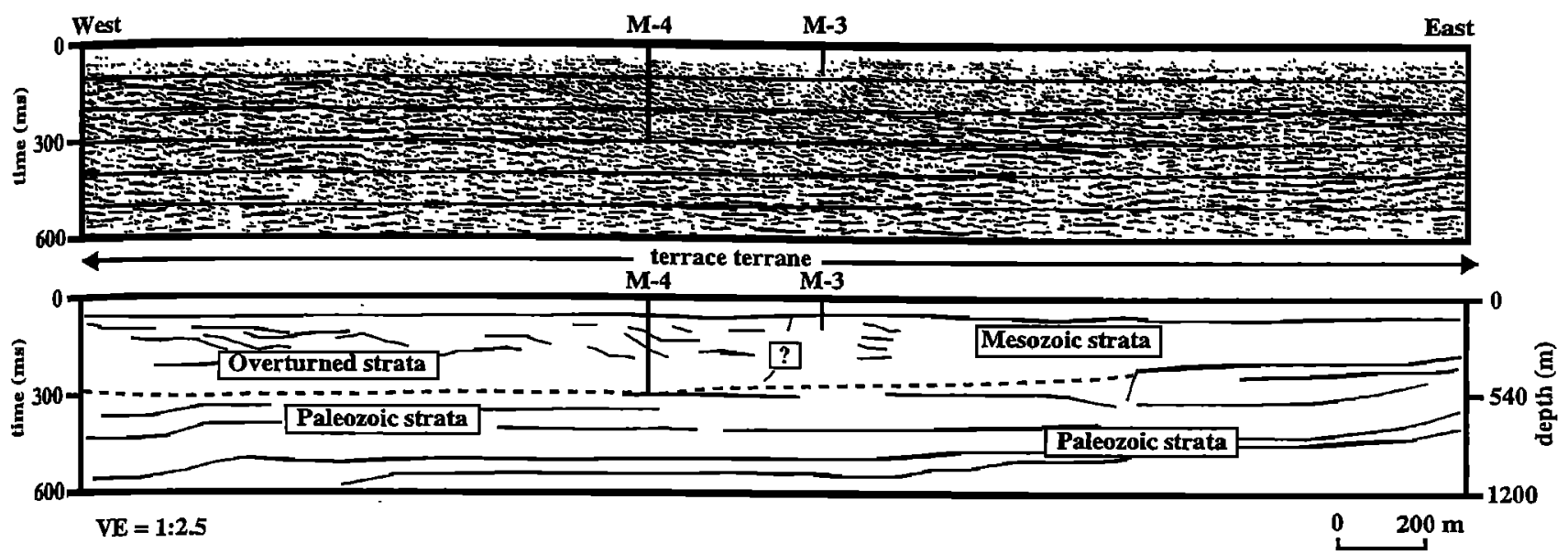

Figure 4e. Continuation of CDP-processed, high-resolution seismic reflection line. See Figure 4a caption for additional details.

from the Paleozoic section serve as markers and identify coherent blocks of material. The size of these blocks along the line, as imaged by line 2, is typically less than $200 \mathrm{~m}$ in length [Keiswetter et al., 1995].

Overturned layers of highly deformed but identifiable stratigraphic sequences are reported in terrestrial impact structures [Cooper, 1977; Offield and Pohn, 1977; Roddy, 1977] and explosion craters [Short, 1965; Roddy, 1976] and are identified in the M-4 well at the MIS [Anderson et al., 1992, 1993]. The high-resolution seismic response of the inverted geology, as identified in the M-4 well, is characterized by laterally limited but highly reflective events (Figure 4e). Although the eastern limit of the overturned sequence, between the $M-3$ and $M-4$ boreholes, is identifiable, the western end is difficult to discern from these seismic data. Based on general impact models and on our interpretation of the high-resolution data, we believe that the western limit of overturned strata coincides with the location of the prominent Paleozoic block located east of marker C (Figure 6). This interpretation is unconstrained.

The reflector that identifies the top of the Proterozoic crystalline basement dips to the east approximately 4 degrees

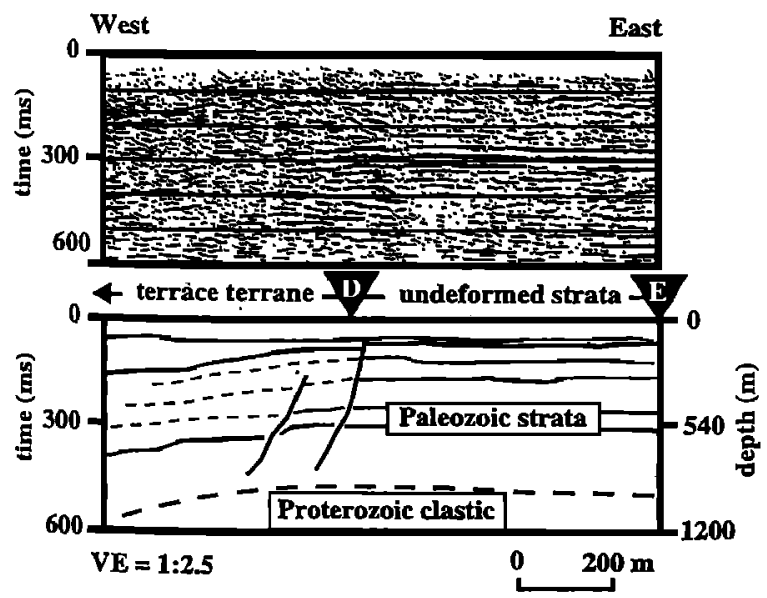

Figure 4f. Continuation of CDP-processed, high-resolution seismic reflection line. See Figure 4 a caption for additional details. within the terrace terrane. The amplitude, frequency content, and coherency of this event is slightly lower within the terrace terrane than in the undeformed region (discussed below).

\section{Undeformed Strata}

Regionally flat-lying Paleozoic units are highly reflective in this area [Chandler et al., 1989], have been identified in borehole data located approximately $55 \mathrm{~km}$ to the southwest [Witzke, 1990], and are imaged along the eastern end of lines 1 and 2 between markers $D$ and $E$ (Figures 3 and $4 f$ ). The Paleozoic units, which are identified by reflection amplitude and coherency, occur between depths of $50 \mathrm{~m}$ to $800 \mathrm{~m} \mathrm{(60} \mathrm{ms} \mathrm{to}$ $500 \mathrm{~ms}$ two-way travel time). Stratigraphic variations within the Paleozoic strata are observed in line 2.

The contact between the Paleozoic sedimentary rocks and the underlying Proterozoic clastics is identified by a general decrease in reflector amplitude and coherency in line 1 (Figure 3). The Proterozoic clastics, which are characterized by lowamplitude subparallel reflectors, attain a maximum thickness of approximately $2.4 \mathrm{~km}$ along the seismic line.

A positive, high-amplitude reflection event identifies the interface between the Proterozoic clastics and the underlying Proterozoic crystalline rocks (line 1, Figure 3). Beneath this boundary, the seismic signature is characterized by subparallelto-wavy, moderate-amplitude events. We observe no laterally coherent seismic reflection events present within the crystalline basement complex.

\section{Discussion}

Complex impact craters are structurally characterized by an uplifted central region, consisting of a central peak, concentric rings, or both, by an annular trough, and by a normally faulted rim area [e.g., Melosh, 1989; Grieve and Pesonen, 1992]. All of the features, with the exception of concentric rings, are interpreted in seismic reflection data acquired at Manson. Contrary to the conclusions of Officer et al. [1992], these seismic data indicate that the geology at Manson is not "orderly".

\section{Amount of Structural Uplift}

An empirical relationship between the amount of structural uplift (SU) and the apparent diameter $\left(D_{a}\right)$ for terrestrial 

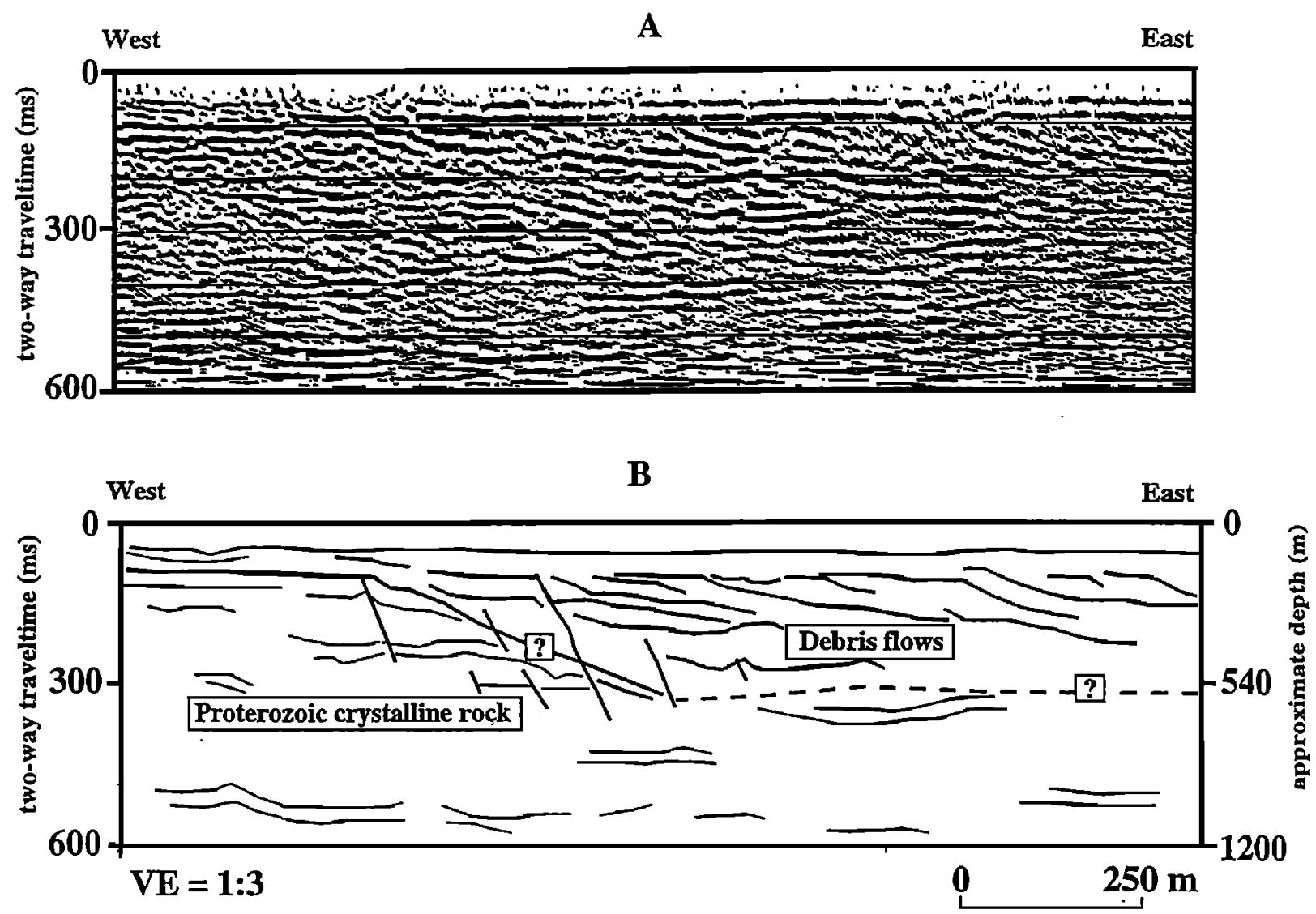

Figure 5. Multichannel high-resolution CDP-stacked data along the edge of the central uplift. Although the annular trough is seismically transparent on the Vibroseis line (Figure 3), stratigraphic details are observed in the high-resolution reflection data (Figure 5a). We interpret the sigmoidal seismic signatures (Figure 5b) to either represent impact breccia that slumped off the central uplift or debris flows that were horizontally transported from outside of the crater.
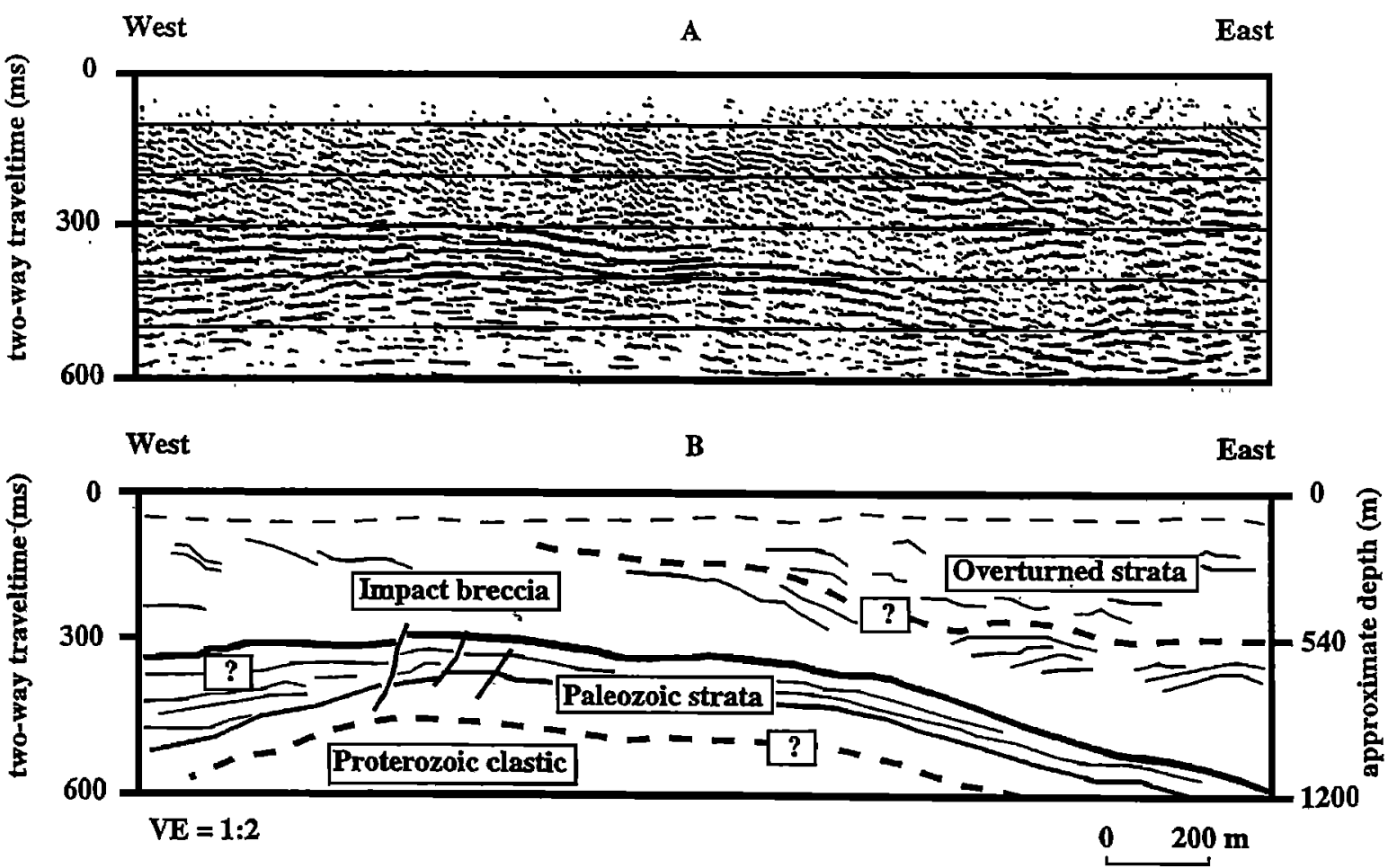

Figure 6. CDP-stacked high-resolution section of the western edge of the terrace terrane; (a) processed section, (b) interpretation (compare Figure 3b). Indications of normal faulting and laterally varying stratigraphy is observed within the Paleozoic strata. 


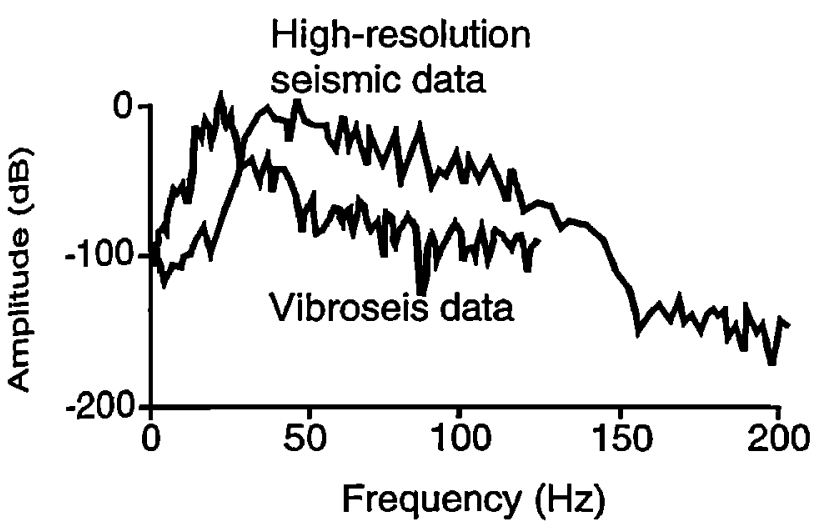

Figure 7. Comparison of the frequency-versus-amplitude spectra between the CDP-stacked high-resolution seismic data and the Vibroseis data. These spectra are averaged over the easterm $1.6 \mathrm{~km}$ of the line (Figures 1,3 , and 4). The highresolution data contain frequencies of up to approximately 150 $\mathrm{Hz}$, whereas the Vibroseis sweeps were limited to frequencies u to $50 \mathrm{~Hz}$.

complex craters is $\mathrm{SU}=0.06 D_{a^{1.1}}$ [Grieve et al., 1981]. Using our interpreted apparent diameter of $35 \mathrm{~km}$, which is identical to the estimate of Anderson and Hartung [1992], this relationship predicts approximately $3.0 \mathrm{~km}$ of uplift. The seismic data indicate a minimum of approximately $2.8 \mathrm{~km}$ of uplift. This estimate is made by calculating the difference between the drilling-confirmed depth of crystalline rock at the central uplift and a linear extrapolation of the interpreted, crystalline-rock interface depth. The agreement between the two estimates is unusually good considering potential errors in seismic velocity analysis and associated inaccuracies in the time-to-depth conversion.

Estimates of the kinetic energy at impact and impactor diameter for the MIS are discussed by Roddy et al. [1993].

\section{Resolution Comparison}

The frequency bandwidth of line 2 is noticeably different than the bandwidth of the Vibroseis data (Figure 7). The high- resolution data contain frequencies of up to approximately 150 $\mathrm{Hz}$ whereas the Vibroseis sweeps were limited to frequencies up to $50 \mathrm{~Hz}$. A portion of data from the undisturbed zone illustrates the resolution differences between lines 1 and 2 and demonstrates how the data sets compliment each other (Figure 8). The reflection event at $240 \mathrm{~ms}$, eastern portion of Figure 8 , is the first coherent seismic signal observed in the Vibroseis data and consists of a single positive peak. Data from line 2, in contrast, clearly show coherent seismic events as early as $80 \mathrm{~ms}$ two-way travel time, as well as laterally varying stratigraphy within the Paleozoic units.

\section{Stratigraphy Adjacent to the Central Uplift}

Seismic reflection data have aided the analysis of the Montagnais Structure, Nova Scotia, Canada. The Montagnais Structure is $45 \mathrm{~km}$ in diameter and $2.7 \mathrm{~km}$ deep and possesses a central uplift with a peak pit [Jansa et al., 1989]. A thick section of melt rock and impact breccia, known to be present through drilling, is interpreted by Jansa et al. [1989] to cap the central uplift. Jansa et al. [1989] suggest that the breccia cap material is preserved due perhaps to decreased erosion, since the Montagnais impact occurred in the ocean. If this argument is valid, the presence of clastic wedges surrounding the central uplift at Manson may represent late stage clastic deposition of material from the central uplift into the Cretaceous seaway.

\section{Crater Model}

The seismic reflection method has successfully imaged craterlike structures at the MIS site and allowed the development of a general crater model. A possible sequence of events leading to the present configuration of the MIS is presented in Figure 9 and is based upon our interpretation of the seismic data, previous work by Anderson and Hartung [1992], and general impact models. The generalized preimpact stratigraphy is shown in Figure 9a. Upon impact the Mesozoic and Paleozoic sediments at ground zero were vaporized, melted, or ejected from the crater (Figure 9b). The impact-induced accelerations displaced portions of the Proterozoic clastic rocks downward and outward as the transient crater increased to its maximum size. During transient crater growth, a sequence of Paleozoic strata was stratigraphically overtumed and dynamically deposited along

West

East

high-

high-

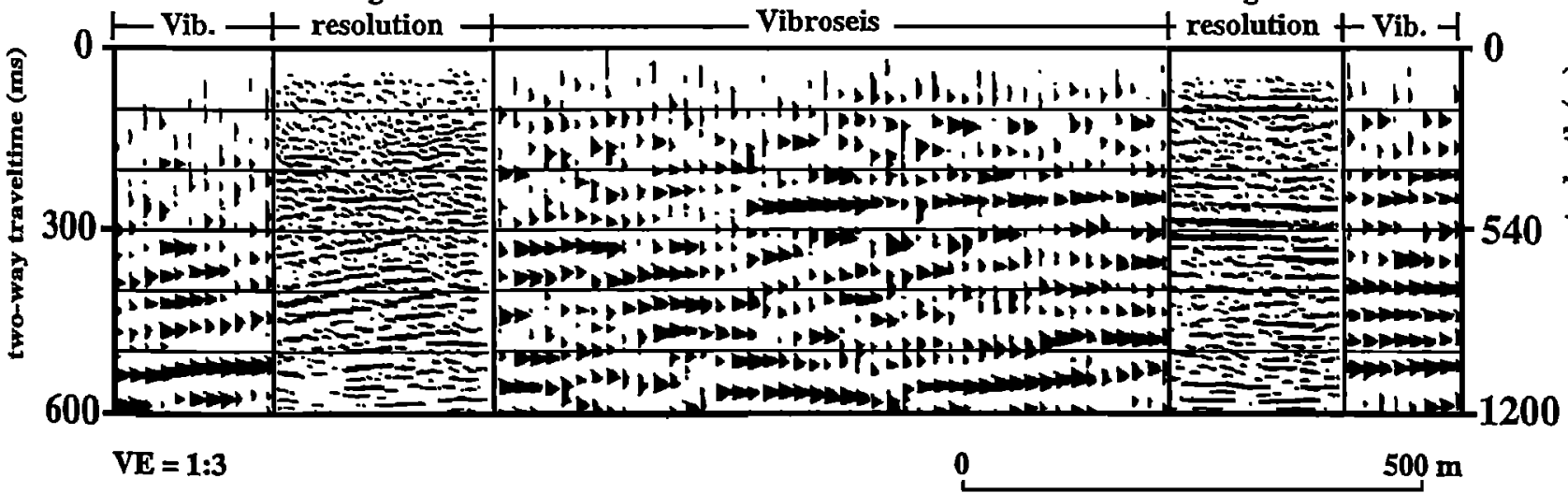

Figure 8. Time domain comparison of the high-resolution and Vibroseis reflection data, located at the boundary between the apparent crater and the undeformed strata (compare Figure 1, 3, and 4f). The two data sets are correlative. Interpretations from the two data sets are complementary due to the inherent differences in resolution and depth-of-energy penetration. 

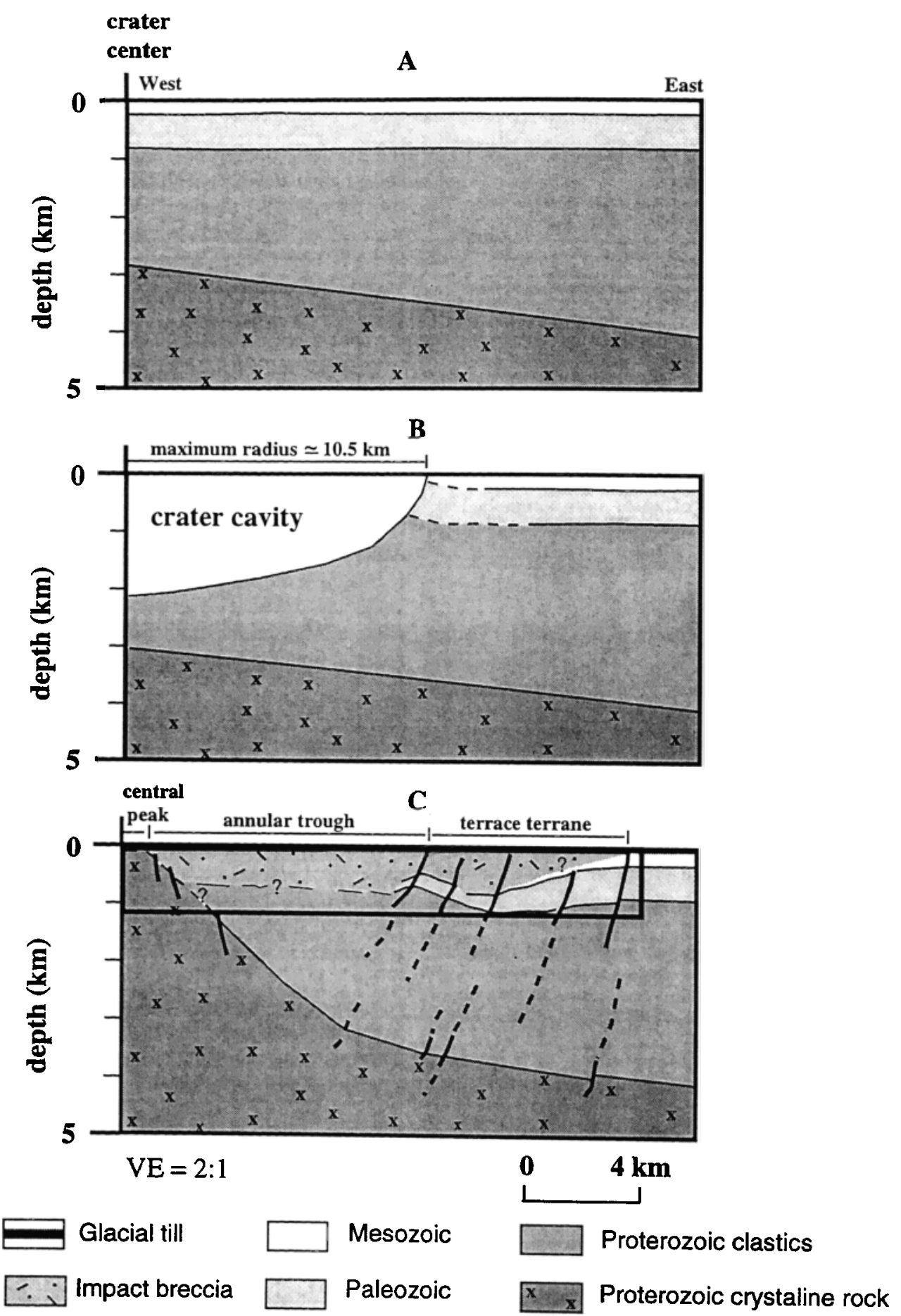

Figure 9. Possible sequence of events leading to the present-day structural configuration of the Manson Impact Structure; (a) preimpact geology, (b) maximum transient crater growth, and (c) present-day configuration. The stippled rectangle in Figure $9 \mathrm{c}$ is the portion of the crater imaged by the high-resolution reflection data (a line drawing interpretation is shown in Figure 10).

margins of the transient crater. Subsequent crater modifications included the slumping of large and small blocks into the transient crater and the formation of a centralized uplift, consisting of Proterozoic clastic and brecciated crystalline rock (Figure 9c). As the crater floor began to rise, debris flows and impact breccia filled the transient crater. Clastic wedges that flank the central uplift, imaged by the high-resolution data represent impact breccia that either slumped off the central uplift or was horizontally transported over $10 \mathrm{~km}$ horizontally. The flow of Proterozoic crystalline material toward the center of the crater enhanced normal faulting and deformation within the terrace terrane. The extent of postcrater deposition of Tertiary marine and fluvial sediments is not well known due to erosion [Anderson and Hartung, 1992]. The crater was subsequently covered by $40 \mathrm{~m}$ of glacial till during the Pleistocene [Ruhe, 1969]. 


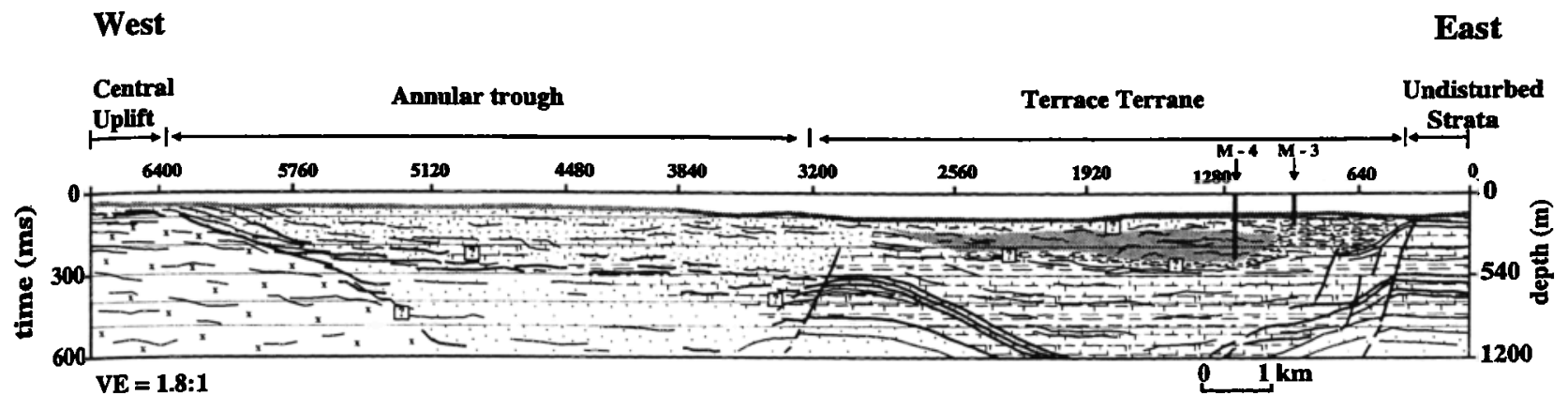

\begin{tabular}{|c|c|c|c|}
\hline Glacial till & Overturned sequence & Paleozoic strata & Proterozoic crystalline rocks \\
\hline Undifferentiated Impact Breccia & 图 Mesoxoic strata & $\square$ Proterozoic clastics & \\
\hline
\end{tabular}

Figure 10. Line drawing interpretation of the Manson Impact Structure based on the high-resolution reflection data. The depths indicated are approximate due to changes in the velocity function along the line. Many of the small-scale features observed in the high-resolution data (Figures 4a-4f) are too small to be included at this scale.

The interpretation of structures observed on the highresolution line (reflectors less than $1.2 \mathrm{~km}$ in depth) is schematically illustrated in Figure 10. The major structural trends interpreted in the high-resolution reflection data strengthen and enhance interpretations of the Vibroseis data. At the scale shown in Figure 10, only the events that are traceable over hundreds of feet can be represented.

\section{Conclusions}

Analysis of Vibroseis and high-resolution seismic reflection data over the Manson Impact Structure, Iowa, indicates that the subsurface structures closely resemble general impact models and other known terrestrial impact craters. Individual interpretations of the MIS Vibroseis and high-resolution seismic data are complementary. This is due, in part, to the trade off between resolution and depth-of-energy penetration. The Vibroseis data successfully image the gross structural features, such as the presence of a central uplift, the approximate boundaries of the apparent crater, and the normal-faulted terrace tertane. The high-resolution data target small-scale features within the upper $1000 \mathrm{~m}$ of the MIS and allow drill core information to be extrapolated away from the well bore. Our structural interpretations strengthen and support previous MIS models [Anderson and Hartung, 1992].

The MIS central uplift is estimated to have a minimum diameter of over $7 \mathrm{~km}$ and to have undergone at least $2.8 \mathrm{~km}$ of uplift. The annular trough that surrounds the central peak is estimated to be 0.6 to $0.7 \mathrm{~km}$ deep. Sigmoidal seismic signatures that flank the central uplift are interpreted to represent impact breccia and debris flow material that either slumped off the central peak or was horizontally transported from outside the crater. The occurrence of clastic wedges at the edge of the central uplift and the shallow crater floor may support the hypothesis that the impact occurred in the Cretaceous seaway. Assuming radial symmetry, the interpreted annular trough diameter is $21 \mathrm{~km}$. The boundary between the annular trough and the terrace terrane is identified by a distinct change in reflection character and the presence of a prominent subsurface block of Paleozoic strata. The terrace terrane is characterized by a series of normally faulted blocks.
Stratigraphically overturned strata that are identified in drill data are seismically characterized by a highly reflective but somewhat chaotic signature. The edge of the apparent crater is identified by a series of normal faults, an increase in depth of the Paleozoic reflectors, and a decrease in the signal-to-noise ratio. Coherent, undeformed strata are imaged outside of the apparent crater. Assuming radial symmetry, the diameter of the MIS is interpreted to be $35 \mathrm{~km}$.

\section{Appendix: Processing Flow}

Data format conversion, geometry application, automatic gain control scale, FK filter, frequency filter (time varying), velocity analysis, normal moveout, dip-moveout (Kirchhoff), normal moveout (inverse), trace edit, first arrival mute, surgical mute, elevation corrections, common-depth-point sort, velocity analysis, CDP stack, and migration.

Acknowledgments. This research was funded by the National Science Foundation contract EAR-9211602. We are grateful to Amoco Production Research Company for releasing the Vibroseis seismic data and to Don Wagner (Amoco Production Research) for overseeing the data transfer process. Without Don's help this study would not be possible. We also thank Rick Miller and seismic crew members from the Kansas Geological Survey for working with us to acquire the highresolution seismic data. The insightful and constructive criticism of Richard Grieve, David Roddy, the Editor, and the Associate Editor is gratefully acknowledged. We believe that the revision process greatly improved this paper.

\section{References}

Anderson, R. R., The midcontinent rift of Iowa, Ph.D. thesis, Univ. of Iowa, Iowa City, 1992.

Anderson, R. R, and J. B. Hartung, The Manson Impact Structure, Iowa, and its contribution to impact materials observed at the CretaceousTertiary boundary, Proc. Lunar Planet. Sci., 22, 101-110, 1992.

Anderson, R. R., J. B. Hartung, M. K. Reagan, M. S. Bell, and O. Plocher, First results from the Manson Impact Structure core-drilling project: Preliminary observations and interpretations from the M-1 core (abstract), Lunar Planet. Sci., XXIII, 31-32, 1992. 
Anderson, R. R., B. J. Witzke, J. B. Hartung, E. M. Shoemaker, and D. J. Roddy, Descriptions and preliminary interpretations of cores recovered from the Manson Impact Structure, Iowa (abstract), Lunar Planet. Sci., XXJV, 35-36, 1993.

Anderson, W., Geology of Iowa, lowa State Univ. Press, Ames, 1983.

Blum, J. D., C. P. Chamberlain, M. P. Hingston, and C. Koeberl, Strontium and oxygen isotope study of the $\mathrm{M}-1, \mathrm{M}-3$, and $\mathrm{M}-4$ drill core samples from the Manson Impact Structure, Iowa: Comparison with Haitian K-T impact glasses (abstract), Lunar Planet. Sci., XXIV, 135-136, 1993.

Chandler, V. W., P. L. MaSwiggen, G. B. Morey, W. J. Hinze, and R. R. Anderson, Interpretation of seismic reflection, gravity, and magnetic data across middle Proterozoic Mid-Continent Rift system, northwestern Wisconsin, eastern Minnesota, and central Iowa, AAPG Bull, 73, 261$275,1989$.

Cooper, H. F., A summary of explosion cratering phenomena relevant to meteor impact events, in Impact and Explosion Cratering, Planetary and Terrestrial Implications, edited by D. J. Roddy, R. O. Pepin, and R. B. Merrill, pp. 11-44, Pergamon, New York, 1977.

Dence, M. R, R A F. Grieve, and P. B. Robertson, Terrestrial impact structures: Principal characteristics and energy considerations, in Impact and Explosion Cratering, Planetary and Terrestrial Implications, edited by D. J. Roddy, R O. Pepin, and R. B. Merrill, pp. 247-275, Pergamon, New York, 1977.

Dryden, J. E., A study of a well core from crystalline rocks near Manson, Iowa, M.S. thesis, Univ, of Iowa, lowa City, 1955.

Grieve, R. A F., and L. J. Pesonen, The terrestrial impact cratering process, Tectonophysics, 216, 1-30, 1992.

Grieve, R. A F., P. B. Robertson, and M. R. Dence, Constraints on the formation of ring impact structures, based on terrestrial data, Proc. Lunar Planet. Sci. Conf., J2A, 37-57, 1981

Hartung, J. B., and R. R Anderson, The Manson Impact Structure and the probability of a K-T boundary age by chance, Eos Trans. $A G U, 70,601$, 1989.

Hartung J. B., M. J. Kunk, and R. R. Anderson, Geology, geophysics, and geochronology of the Manson Impact Structure, in Global Catastrophes in Earth History: An Interdisciplinary Conference o Impacts, Volcanism, and Mass Mortality, edited by V. L. Sharpton and P. D. Ward, Spec. Pap., Geol. Soc. Am., 247, 207-221, 1990.

Hartung, J., A Kracher, R. Anderson, and O. Plocher, Manson Impact Structure rocks: Evidence for an exotic component (abstract), Lunar Planet. Sci., XXIII, 497-498, 1992.

Hildebrand, A R, and W. V. Boynton, Proximal Cretaceous-Tertiary boundary impact deposits in the Caribbean, Science, 248, 843-847, 1990.

Hoppin, R. A, and J. E. Dryden, An unusual oceurrence of Pre-Cambrian crystalline rocks beneath glacial drift near Manson, Iowa, J. Geol, 66, 694-699, 1958.

Izett, G. A, W. A Cobban, J. D. Obradovich, and M. J. Kunk, The Manson Impact Structure: ${ }^{40} \mathrm{Ar} / 39 \mathrm{Ar}$ age and its distal impact ejecta in the Pierre Shale in southeastern South Dakota, Science, 262, 729-732, 1993.

Jansa, L. F., G. Pe-Piper, P. B. Robertson, and $O$. Friendenreich, Montagnais: A submarine impact structure in the Scotian Shelf, eastem Canada, Geol. Soc. Am. Bull, 101, 450-463, 1989.

Juhlin, C., and L. B. Pedersen, Reflection seismic investigation of the Siljan Impact Structure, Sweden, J. Geophys. Res., 92, 14113-14122, 1987.

Keiswetter, D., R. Black, and D. Steeples, Mapping bedrock beneath glacial till using CDP seismic reflection methods, Geophys. Res. Lett, 21, 453456, 1994

Keiswetter, D., R. Black, and D. Steeples, Structure of the terrace terrane, Manson Impact Structure, Iowa, interpreted from high-resolution seismic-reflection data, in Manson Impact Structure, edited by $\mathrm{C}$. Koeberl and R. R. Anderson, Spec. Pap. Geol. Soc. Am, 302, in press, 1995.

Kirschner, C., A. Grantz, and M. W. Mullen, Impact origin of the Avak Structure, Arctic Alaska, and Genesis of the Barrow Gas Fields, AAPG Bull., 76, 651-679, 1992.

Koerbel, C., and R. R. Anderson (Eds.), Manson Impact Structure, Spec. Pap. Geol. Soc. Am, 302, 1995.

Koeberl, C., R. R. Anderson, J. B. Hartung, and W. U. Reimold, Manson Impact Structure, lowa: First geochemical results for drill core M-1 (abstract), Lunar Planet. Scl., XXN, 811-812, 1993.

Kunk, M. J., G. A. Izett, and J. F. Sutter, ${ }^{40} \mathrm{Ar} /{ }^{39} \mathrm{Ar}$ age spectra of shocked
K-feldspar suggest K-T boundary age for Manson, Iowa, Impact Structure, Eos Trans. $A G U, 68,1514,1987$.

Kunk, M. J., G. A. Izett, R. A. Haugerud, and J. E. Sutter, ${ }^{40} \mathrm{Ar} /{ }^{39} \mathrm{Ar}$ dating of the Manson Impact Structure; A Cretaceous-Tertiary boundary candidate, Science, 232, 1225-1229, 1989.

Melosh, H. J., A schematic model of crater modification by gravity, J. Geophys. Res., 87, 371-380, 1982.

Melosh, H. J., Acoustic fluidization, Am. Sci., 71, 158-165, 1983.

Melosh, H. J., Impact Cratering, a Geologic Process, Oxford Univ. Prew New York, 1989.

Officer, C. B., C. Drake, J. L. Pindell, and A. A. Meyerhoff, CretaceousTertiary events and the Caribbean caper, GSA Today, 2(4), 69-75, 1992.

Offield, T. W., and H. A. Pohn, Deformation at the Decaturville impact structure, Missouri, in Impact and Explosion Cratering, Planetary and Terrestrial Implications, edited by D. J. Roddy, R O. Pepin, and R B. Merrill, pp. 321-341, Pergamon, New York, 1977.

Poag, C., D. Powars, L. Poppa, and R. Mixon, Meteorioid mayhem in Ole Virginny: Source of the North American tektite strewn field, Geology, 22, 691-694, 1994.

Pohl, J., D. Stoffler, D. Gall, and K. Emstson, The Ries impact crater, in Impact and Explosion Cratering, Planetary and Terrestrial Implications, edited by D. J. Roddy, R. O. Pepin, and R B. Merrill, pp. 343-404, Pergamon, New York, 1977.

Roddy, D. J., High-explosive cratering analogs for bowl-shaped, central uplif, and multiring impact craters, Proc. Lunar Sci. Conf., 7th, 3027. 3056, 1976.

Roddy, D. J., Large-scale impact and explosion craters: comparisons of morphological and structural analogs, in Impact and Explosion Cratering, Planetary and Terrestrial Implications, edited by D. J. Roddy, R. O. Pepin, and R B. Merrill, pp. 185-246, Pergamon, New York, 1977.

Roddy, D. J., E. M. Shoemaker, and R. R. Anderson, The Manson Impac Crater: Estimation of the energy of formation, possible size of the impacting asteroid or comet, and ejecta volume and mass (abstract), Lunar Planet. Sci., XXIV, 1211-1212, 1993.

Ruhe, R. V., Quaternary Landscapes in Iowa, Iowa State Univ. Press Ames, 1969.

Sawatzky, H., Astroblemes in Williston Basin, AAPG Bull., 59, 694710, 1975.

Sawatzky, H., Two probable late Cretaceous astroblemes in western Canada-Eagle Butte, Alberta and Dumas, Saskatchewan, Geophysics, $41,1261-1274,1976$.

Sawatzky, H., Buried impact craters in the Williston Basin and adjacent areas, in Impact and Explosion Cratering, Planetary and Terrestrial Implications, edited by D. J. Roddy, R. O. Pepin, and R. B. Merrill, pp. 461-480, Pergamon, New York, 1990.

Sharpton, V., and R. Grieve, Meteorite impact, cryptoexplosion, and shock metamorphism; A perspective on the evidence at the K/T boundary, in Global Catastrophes in Earth History: An Interdisciplinary Conference on Impacts, Volcanism, and Mass Mortality, edited by V. L. Sharpton, and P. D. Ward, Spec. Pap. Geol. Soc. Am., 247, 301-328, 1990.

Short, N. M., A comparison of features characteristic of nuclear explosion craters and astroblemes, Ann. N.Y. Acad. Sci., 123, 573-616, 1965.

Short, N. M., Shock processes in geology, J. Geol Educ., 14(4), 149-166, 1966.

Short, N. M., and D. P. Gold, Petrography of shock features in the 1953 Manson 2-A drill core (abstract), Lunar Planet Sci., XXTV, 1303-1304, 1993.

Witzke, B. W., General stratigraphy of the Phanerozoic and Keweenawan Sequence, M. G. Eischeid \#1 drillhole, Carroll County, Iowa, in The Amoco M. G. Eischeid\#I Deep Petroleum Test, Carroll County, Iowa: Preliminary Investigations, edited by R R Anderson, Spec. Rep. Ser. 2, pp. 39-58, Iowa Dep. of Nat. Resourc. Geol. Surv. Bur., Iowa City, 1990.

R. Black and D. Steeples, Department of Geology, University of Kansas, 120 Lindley Hall, Lawrence, KS 66045.

D. Keiswetter, Geophex, Ltd., 605 Mercury Street, Raleigh, NC 27603.

(Received January 19, 1995; revised October 2, 1995;

accepted October 6,1995 .) 